University of Nebraska - Lincoln

DigitalCommons@University of Nebraska - Lincoln

$9-2011$

\title{
Bioenergy Feedstock-Specific Enrichment of Microbial Populations During High-Solids Thermophilic Deconstruction
}

\author{
Amitha P. Reddy \\ Joint BioEnergy Institute, APReddy@lbl.gov \\ Martin Allgaier \\ Joint BioEnergy Institute \\ Steven W. Singer \\ Joint BioEnergy Institute, SWSinger@lbl.gov \\ Terry C. Hazen \\ Joint BioEnergy Institute \\ Blake A. Simmons \\ Joint BioEnergy Institute, BASimmons@lbl.gov \\ See next page for additional authors
}

Follow this and additional works at: https://digitalcommons.unl.edu/usdoepub

Part of the Bioresource and Agricultural Engineering Commons

Reddy, Amitha P.; Allgaier, Martin; Singer, Steven W.; Hazen, Terry C.; Simmons, Blake A.; Hugenholtz, Philip; and VanderGheynst, Jean S., "Bioenergy Feedstock-Specific Enrichment of Microbial Populations During High-Solids Thermophilic Deconstruction" (2011). US Department of Energy Publications. 346. https://digitalcommons.unl.edu/usdoepub/346

This Article is brought to you for free and open access by the U.S. Department of Energy at DigitalCommons@University of Nebraska - Lincoln. It has been accepted for inclusion in US Department of Energy Publications by an authorized administrator of DigitalCommons@University of Nebraska - Lincoln. 


\section{Authors}

Amitha P. Reddy, Martin Allgaier, Steven W. Singer, Terry C. Hazen, Blake A. Simmons, Philip Hugenholtz, and Jean S. VanderGheynst 


\title{
Bioenergy Feedstock-Specific Enrichment of Microbial Populations During High-Solids Thermophilic Deconstruction
}

\author{
Amitha P. Reddy, ${ }^{1,2}$ Martin Allgaier, ${ }^{1,3}$ Steven W. Singer, ${ }^{1,4}$ Terry C. Hazen, ${ }^{1,4}$ \\ Blake A. Simmons, ${ }^{1,5,6}$ Philip Hugenholtz, ${ }^{1,3,7}$ Jean S. VanderGheynst ${ }^{1,2}$ \\ ${ }^{1}$ Joint BioEnergy Institute, Emeryville, California \\ ${ }^{2}$ Biological and Agricultural Engineering, University of California, Davis, \\ California 95616; telephone:530-752-0989; fax: 530-752-2640; e-mail: jsvander@ucdavis.edu \\ ${ }^{3}$ DOE Joint Genome Institute, Walnut Creek, California \\ ${ }^{4}$ Earth Sciences Division, Lawrence Berkeley National Laboratory, Berkeley, California \\ ${ }^{5}$ Physical and Life Sciences Directorate, Lawrence Livermore National Laboratory, \\ Livermore, California \\ ${ }^{6}$ Biomass Science and Conversion Technology Department, Sandia National Laboratories, \\ Livermore, California \\ ${ }^{7}$ Australian Centre for Ecogenomics, School of Chemistry and Molecular Biosciences, \\ The University of Queensland, St Lucia, Queensland, Australia \\ Received 23 January 2011; revision received 28 March 2011; accepted 4 April 2011 \\ Published online 21 April 2011 in Wiley Online Library (wileyonlinelibrary.com). DOI 10.1002/bit.23176
}

\begin{abstract}
Thermophilic microbial communities that are active in a high-solids environment offer great potential for the discovery of industrially relevant enzymes that efficiently deconstruct bioenergy feedstocks. In this study, finished green waste compost was used as an inoculum source to enrich microbial communities and associated enzymes that hydrolyze cellulose and hemicellulose during thermophilic high-solids fermentation of the bioenergy feedstocks switchgrass and corn stover. Methods involving the disruption of enzyme and plant cell wall polysaccharide interactions were developed to recover xylanase and endoglucanase activity from deconstructed solids. Xylanase and endoglucanase activity increased by more than a factor of 5, upon four successive enrichments on switchgrass. Overall, the changes for switchgrass were more pronounced than for corn stover; solids reduction between the first and second enrichments increased by a factor of four for switchgrass while solids reduction remained relatively constant for corn stover. Amplicon pyrosequencing analysis of small-subunit ribosomal RNA genes recovered from enriched samples indicated rapid changes in the microbial communities between the first and second enrichment with the simplified communities achieved by the third enrichment. The results demon-
\end{abstract}

Martin Allgaier's present address is Leibniz-Institute of Freshwater Ecology and Inland Fisheries, 12587 Berlin, Germany.

Jean S. VanderGheynst's present address is Department of Biological and Agricultural Engineering, One Shields Ave., Davis, CA 95161.

Correspondence to: J.S. VanderGheynst

Contract grant sponsor: US Department of Energy, Office of Science, Office of

Biological and Environmental Research strate a successful approach for enrichment of unique microbial communities and enzymes active in a thermophilic high-solids environment.

Biotechnol. Bioeng. 2011;108: 2088-2098.

(C) 2011 Wiley Periodicals, Inc.

KEYWORDS: switchgrass; corn stover; solid state fermentation; compost; xylanase; endoglucanase

\section{Introduction}

Plant residues and dedicated herbaceous crops have been proposed as viable sources of biomass for liquid fuel production. Limiting factors to their utilization include sustainable harvest, transportation, storage, and conversion to fermentable sugars. Recalcitrance to conversion has been identified as one of the most challenging factors facing utilization (Bohlmann, 2006; Chandra et al., 2007; Yang and Wyman, 2008). This is due in part to expensive deconstruction and hydrolysis of plant cell wall polymers. Industrially robust processes for the conversion of plant cell walls (lignocellulose) to liquid fuels or other products will require enzymes that function under extremes in temperature, solute concentrations, and moisture (Kulkarni et al., 1999; Rubin, 2008). Sources of such enzymes include microbial communities that are currently subjected to many of the extreme conditions expected in industrial plant cell wall conversion systems. One such community is from 
composting which involves the controlled aerobic decomposition of organic matter (VanderGheynst et al., 1997). Composting processes typically include a thermophilic phase to inactivate human and plant pathogens and weed seeds. Also, many processes are turned to facilitate introduction of air and moisture (Marshall et al., 2004). The result is a microbial community that is remarkably robust with the metabolic potential to rapidly degrade plant cell wall polysaccharides in a thermophilic, high-solids environment (Allgaier et al., 2010). These communities offer great potential for the discovery of enzymes that deconstruct plant cell walls at elevated temperature.

In addition to process engineering challenges related to feedstock acquisition and conversion, water will likely be an expensive resource and residue stream that must be effectively managed in biological systems employing plant biomass conversion to fuels (Gerbens-Leenes et al., 2009). Operating hydrolysis and fermentation processes at low moisture levels (high solids) reduces costs associated with water purchase and treatment. High solids conversion processes provide other advantages for industrial scale conversion. For example, lower water levels translate to a lower heat capacity of liquid-biomass mixtures, thereby reducing energy requirements for heating and cooling. Costs for product recovery also decrease with decreasing water in the product stream. However, high solids environments present challenges associated with mixing and more rapid feedback inhibition from hydrolysis products (Merino and Cherry, 2007; Zhang et al., 2010). Identification of enzymes that remain active under such conditions is valuable for industrial scale processes.

The goals of this study were to select microbial communities and secreted enzymes that decompose bioenergy feedstocks in a thermophilic high-solids environment, and to examine the evolution of microbial community structure and enzyme activity during enrichment. Green waste compost was used as a source of inoculum, and switchgrass and corn stover were the sources of feedstock. Both feedstocks show potential for bioenergy production and reducing greenhouse gas emissions (Schmer et al., 2008; Spatari et al., 2005).

To measure enzymatic activity, experiments were necessary to identify extraction conditions that recovered enzymes bound to or trapped within the plant cell wall matrices. Extraction buffer compounds selected for investigation included Tween $80, \mathrm{NaCl}$, and ethylene glycol. Recognizing that the composition of corn stover (cobs, leaves, and stems) and switchgrass (leaves and stems) are very different, two separate studies were completed to identify extraction conditions for each feedstock.

Microbial community structure was monitored using small-subunit ribosomal RNA (SSU rRNA) amplicon pyrosequencing based on the high-throughput Roche 454 sequencing platform. Microbial diversity was determined after each incubation cycle over the course of the entire experiment to follow temporal changes and to determine adaptation of specific phylotypes to the provided feedstocks.
The results from the study demonstrate a successful highsolids approach for selecting microbial communities and secreted enzymes for biomass deconstruction. Disruption of hydrophobic interactions between enzymes and plant cell wall polysaccharides was imperative for yielding xylanase and endoglucanase activities from enriched samples.

\section{Materials and Methods}

\section{High-Solids Incubations}

Finished green waste compost was obtained from a commercial facility that composts agricultural residues including tree and vine prunings (Grover Soil Solutions, Zamora, CA). Compost was solar-dried and stored at $4^{\circ} \mathrm{C}$ until applied as inocula.

Corn stover was obtained courtesy of Bruce Dale of Michigan State University (MSU), East Lansing, MI. Corn stover with corn cobs without grains (NK brand N33-J4) was harvested from MSU corn fields in 2008. Switchgrass stem pieces were obtained from the laboratory of Dr. Ken Vogel of USDA-ARS, University of Nebraska, Lincoln, NE.

The biomass was size reduced using a leaf shredder and air dried until the moisture was $<10 \%$. Then it was further size reduced using a Wiley mill with a $10 \mathrm{~mm}$ screen. Biomass composition of size-reduced samples was measured by Microbac Laboratories, Inc (Pittsburgh, PA). The major components of the switchgrass included lignin $\left(23.2 \% \mathrm{~g} \mathrm{~g}^{-1}\right.$ dry weight), starch $(2.4 \%)$, glucan $(35.5 \%)$, xylan $(19.1 \%)$, and arabinan $(3.1 \%)$. Major corn stover components included lignin $(18.5 \%)$, starch $(3.5 \%)$, glucan $(31.2 \%)$, xylan $(16.7 \%)$, and arabinan $(1.8 \%)$. Both feedstocks were extracted with ethanol for 1.5 days and water for 2 days in a soxhlet extractor. The materials were then dried in a vacuum oven for 4 days and stored in air-tight containers at $4^{\circ} \mathrm{C}$ until needed.

Prior to incubation, extracted switchgrass and corn stover were wetted with minimal media to a target moisture content of $400 \mathrm{wt} \%$ dry basis ( $\mathrm{g}$ water g dry solid $^{-1}$ ) ( $80 \mathrm{wt} \%$ wet basis ( $\mathrm{g}$ water $\mathrm{g}$ total $\left.^{-1}\right)$ ) and allowed to equilibrate at $4{ }^{\circ} \mathrm{C}$ overnight. Feedstocks were inoculated with $10 \mathrm{wt} \%$ ( $g$ dry compost $\mathrm{g}_{\text {dry solid }}{ }^{-1}$ ) compost immediately before incubation.

High-solids incubations were done for each feedstock and conducted as previously described (Reddy et al., 2009). Briefly, bioreactors with a $0.2 \mathrm{~L}$ working volume were loaded with 10-11 g dry weight of feedstock and compost mixture. Air was supplied to each bioreactor at $10 \mathrm{~mL} \mathrm{~min}^{-1}$ to maintain aerobic conditions. Incubator temperature was maintained at $35^{\circ} \mathrm{C}$ for 1 day, ramped to $55^{\circ} \mathrm{C}$ over 1 day, and held at $55^{\circ} \mathrm{C}$ for the duration of the experiment. Temperature was monitored with a HOBO data logger (Onset Computer Corporation, Bourne, MA). To maintain a moisture content ideal for microbial activity, water was added to each bioreactor and the contents were mixed every 3.5 days. 
The respiration rate of the microbial community, represented as $\mathrm{CO}_{2}$ evolution rate (CER), was measured for all incubated samples. Carbon dioxide concentration was measured on the influent and effluent air of the bioreactors using an infrared $\mathrm{CO}_{2}$ sensor (Vaisala, Woburn, MA) and flow was measured with a thermal mass flow meter (Aalborg, Orangeburg, NY). Carbon dioxide and flow data were recorded every $20 \mathrm{~min}$ using a data acquisition system; CER and cumulative respiration (cCER) were calculated as previously described (Reddy et al., 2009).

For experiments to identify the enzyme extraction buffer, one bioreactor for each feedstock was inoculated and aerated for 8 days before harvesting. For the long-term enrichment study, each feedstock was incubated in triplicate; three switchgrass (S11, S14, and S16) and three corn stover (C12, $\mathrm{C} 13$, and C15) communities were allowed to develop in parallel. Every 2 weeks, feedstock samples containing each enriched community were collected. Fresh feedstock was inoculated with $10 \mathrm{wt} \%$ (g dry enriched sample g total dry weight ${ }^{-1}$ ) of the enriched community and transferred to a new bioreactor. The long-term enrichment experiment ran for 8 weeks yielding a total of four time points (T1, T2, T3, and T4) for enzyme and microbial community analyses.

At the end of each incubation, samples were collected for measurement of enzyme activity, microbial community structure (long-term incubation only), and moisture content. Methods for enzyme activity and microbial community structure are described in detail in later sections of this article. Moisture content was measured gravimetrically after drying samples at $105^{\circ} \mathrm{C}$ for $24 \mathrm{~h}$.

\section{Identification of Buffer Components for Enzyme Extraction From Solid Samples}

Significant components for the enzyme extraction buffer were identified using full factorial studies with three center-point replicates (Table I). Each study was conducted with the three following components: ethylene glycol (0-50 wt \%), Tween 80 (0.01-0.15 wt\%), and sodium chloride $(0.1-1.5 \mathrm{wt} \%)$. A sodium acetate buffer $(50 \mathrm{mM}$, $\mathrm{pH}=5.0)$ control was also examined.

Three grams (wet weight) of freshly harvested colonized feedstock was shaken with $27 \mathrm{~g}$ of each buffer for $60 \mathrm{~min}$ at $150 \mathrm{RPM}$ and room temperature. Samples were centrifuged at $4{ }^{\circ} \mathrm{C}$ and $10,000 \mathrm{~g}$ for $20 \mathrm{~min}$ and then filtered using $0.2 \mu \mathrm{m}$ membranes.

To reduce interference of the buffer components with enzyme activity measurements, the extraction buffer was exchanged with sodium acetate buffer before proceeding with the enzyme activity assays. VivaSpin columns with a PES membrane and a $5 \mathrm{kDa}$ molecular weight cut off (VWR, West Chester, PA) were used.

Activity in dialyzed extracts was measured as described below. JMP statistical software (v. 8.0.1, SAS Institute, Cary, $\mathrm{NC}$ ) was used to perform stepwise regression and determine significant buffer components. Data were used to determine the ideal component levels for the extraction buffer for each feedstock.

\section{Enzyme Extraction From Enriched samples and Activity Assays}

Proteins were extracted from incubated switchgrass and corn stover samples according to the procedure described above using $50 \mathrm{wt} \%$ ethylene glycol, $0.1 \mathrm{wt} \%$ Tween 80 , and $1 \mathrm{wt} \%$ sodium chloride.

Enzyme activities were measured using a 96-well plate reducing sugar assay. All incubations were conducted in an Eppendorf Mastercycler PCR thermal cycler with heated lid (Eppendorf North America, Hauppauge, NY). Endoglucanase activity was measured as described by Xiao et al. (2005) with the following modifications: the total working volume in

Table I. Full factorial experimental design to select buffer for enzyme extraction from switchgrass and corn stover, including resulting enzyme activities in dialyzed extracts.

\begin{tabular}{|c|c|c|c|c|c|c|c|}
\hline \multirow[b]{2}{*}{ Treatment } & \multicolumn{3}{|c|}{ Coded component levels } & \multicolumn{2}{|c|}{ Switchgrass } & \multicolumn{2}{|c|}{ Corn stover } \\
\hline & $\mathrm{NaCl}^{\mathrm{a}}$ & Tween $80^{\mathrm{b}}$ & $\begin{array}{l}\text { Ethylene } \\
\text { glycol }^{\mathrm{c}}\end{array}$ & $\begin{array}{c}\text { Xylanase } \\
\left(\mathrm{IU} \mathrm{g} \mathrm{dw}^{-1}\right)\end{array}$ & $\begin{array}{l}\text { Endoglucanase } \\
\left(\mathrm{IU} \mathrm{g} \mathrm{dw}^{-1}\right)\end{array}$ & $\begin{array}{c}\text { Xylanase } \\
\left(\mathrm{IU} \mathrm{g} \mathrm{dw}^{-1}\right)\end{array}$ & $\begin{array}{c}\text { Endoglucanase } \\
\left(\mathrm{IU} \mathrm{g} \mathrm{dw}^{-1}\right)\end{array}$ \\
\hline 1 & 0 & 0 & 0 & 0.31 & 0.11 & 0.22 & 0.10 \\
\hline 2 & +1 & -1 & -1 & 0.30 & 0.11 & 0.18 & 0.10 \\
\hline 3 & 0 & 0 & 0 & 0.45 & 0.14 & 0.24 & 0.11 \\
\hline 4 & +1 & +1 & +1 & 0.71 & 0.15 & 0.31 & 0.10 \\
\hline 5 & -1 & -1 & -1 & 0.35 & 0.13 & 0.17 & 0.11 \\
\hline 6 & -1 & +1 & +1 & 0.71 & 0.18 & 0.32 & 0.13 \\
\hline 7 & +1 & -1 & +1 & 0.70 & 0.15 & 0.37 & 0.12 \\
\hline 8 & -1 & -1 & +1 & 0.59 & 0.17 & 0.33 & 0.13 \\
\hline 9 & +1 & +1 & -1 & 0.41 & 0.12 & 0.20 & 0.09 \\
\hline 10 & 0 & 0 & 0 & 0.49 & 0.16 & 0.23 & 0.11 \\
\hline 11 & -1 & +1 & -1 & 0.36 & 0.14 & 0.21 & 0.12 \\
\hline 12 & Sodium Acetate buffer control & 0.29 & 0.15 & 0.17 & 0.11 & & \\
\hline
\end{tabular}

${ }^{\mathrm{a}} \mathrm{NaCl}$ settings: $-1=0.1 \mathrm{wt} \%, 0=0.8 \mathrm{wt} \%$, and $+1=1.5 \mathrm{wt} \%$.

b Tween 80 settings: $-1=0.01 \mathrm{wt} \%, 0=0.08 \mathrm{wt} \%$, and $+1=0.15 \mathrm{wt} \%$.

${ }^{\mathrm{c}}$ Ethylene glycol settings: $-1=0 \mathrm{wt} \%, 0=25 \mathrm{wt} \%$, and $+1=50 \mathrm{wt} \%$. 
each well was $160 \mu \mathrm{L}$, the $50 \mathrm{mM}$ sodium acetate buffer had a $\mathrm{pH}$ of 5.0 , and the incubation times were longer. The substrate was $2 \%$ carboxymethylcellulose and the standard curve was made with sterile-filtered glucose dilutions.

Briefly, $40 \mu \mathrm{L}$ of sample was incubated with $40 \mu \mathrm{L}$ of substrate at $50^{\circ} \mathrm{C}$, to allow conversion of cellulose to sugars. The reaction was stopped with $80 \mu \mathrm{L}$ of a dinitrosalicyclic acid (DNS) reagent containing $1.4 \%$ DNS, $1.4 \%$ sodium hydroxide, $28 \%$ Rochelle salts, $0.28 \%$ phenol, and $0.07 \%$ sodium sulfite. Sample blanks and standards were added, and the plate was incubated at $95^{\circ} \mathrm{C}$ for $5 \mathrm{~min}$ to develop color proportional to the reducing ends in the well. Samples were transferred to round-bottom spectrophotometer plates and the color was measured at $540 \mathrm{~nm}$.

To measure xylanase activity, the method described above was combined with the protocol developed by Bailey et al. (1992) and Xiao et al. (2005). The xylanase protocol was identical to the 96-well cellulase assay described above, but the substrate was $1 \%$ birchwood xylan, the standard curve was made with sterile-filtered xylose dilutions, and incubation times were shorter.

\section{DNA Extraction and SSU rRNA Amplicon Pyrosequencing}

Samples from bioreactors at each time point were snap frozen in liquid nitrogen and homogenized with an oscillating ball mill (MM400, Retsch Inc., Newtown, PA). DNA was extracted with a CTAB and bead-beating protocol described elsewhere (Allgaier et al., 2010). A 450 bp fragment of the SSU rRNA gene was amplified using the broadly conserved primer pair $926 \mathrm{~F}-1392 \mathrm{R}$ as described in Engelbrektson et al. (2010). The reverse primer included a 5 bp barcode for multiplexing of samples during sequencing. Barcoded amplicons were mixed in equal proportions prior to emulsion PCR following manufacturer's instructions and sequenced using the Roche 454 GS FLX Titanium technology. Sequencing tags were quality trimmed and analyzed using the pyroclust version of the software tool PyroTagger (Kunin et al., 2010) with a 220 bp sequence length threshold and an accuracy of $10 \%$ for low quality bases.

To reduce noise in statistical analysis all singleton OTUs were removed from the data set. Non-metric multidimensional scaling (NMDS) analyses and calculation of Shannon's diversity indices were performed using the vegan package in the $\mathrm{R}$ software environment (http:// CRAN.R-project.org/package=vegan). NMDS parameters were set to three dimensions and a maximum of 1,000 random starts. Similarity percentage (SIMPER) analysis was performed using the respective function in the PRIMER V software package (Plymouth Marine Laboratory, Plymouth, UK) using default settings.

\section{Results}

\section{Identification of Buffer Components for Enzyme Extraction from Solid Samples}

The extraction buffer for enzyme recovery from incubated solids was determined from a full factorial study in which incubated samples of corn stover and switchgrass were extracted using the components and levels listed in Table I. The largest variations in enzyme activity extracted were for xylanase (Table I). Xylanase activities from switchgrass varied between $0.29 \mathrm{IU} \mathrm{g} \mathrm{dw}^{-1}$ for sodium acetate extraction to $0.71 \mathrm{IU} \mathrm{g} \mathrm{dw}^{-1}$ for extractions containing $50 \mathrm{wt} \%$ ethylene glycol and $0.15 \mathrm{wt} \%$ Tween 80 . Similar to switchgrass, xylanase extraction from corn stover was also highest $\left(0.37 \mathrm{IU} \mathrm{g} \mathrm{dw}^{-1}\right)$ when extractions contained $50 \mathrm{wt} \%$ ethylene glycol.

Endoglucanase extraction also varied with the composition of the buffer, but differences were much smaller compared to xylanase. Like xylanase, the highest activities were observed with extractions containing $50 \mathrm{wt} \%$ ethylene glycol. These were 0.18 and $0.13 \mathrm{IU} \mathrm{g} \mathrm{dw}^{-1}$ for switchgrass and corn stover, respectively.

Ethylene glycol had a significant positive effect on xylanase and endoglucanase extractions from both switchgrass and corn stover $(P$-value $<0.01)$. For switchgrass, sodium chloride and Tween 80 had no significant effect ( $P$-values $>0.05)$ on extraction of enzyme activities.

For xylanase extraction from corn stover, the interaction between Tween 80 and ethylene glycol was significant; when ethylene glycol was at $50 \mathrm{wt} \%$ in the buffer, increasing Tween 80 from 0.01 to $0.15 \mathrm{wt} \%$ reduced extraction $(P$-value $=0.0168)$. Sodium chloride had no significant effect on xylanase activity extracted from corn stover ( $P$-value $>0.05$ ).

Endoglucanase activity extracted from corn stover was low for all samples and varied between 0.09 and $0.13 \mathrm{IU} \mathrm{g} \mathrm{dw}^{-1}$. Sodium chloride had a significant negative effect on endoglucanase activity extracted ( $P$-value $=$ 0.0036). Also, the interaction between sodium chloride and Tween 80 was significant $(P$-value $=0.0368)$; when $\mathrm{NaCl}$ was present at $1.5 \mathrm{wt} \%$ in the buffer, increasing Tween 80 from $0.01 \mathrm{wt} \%$ to $0.15 \mathrm{wt} \%$ reduced extraction.

The conditions selected for extracting enzymes from enriched samples were based on results from the screening study and the ease of sample handling. Extractions with higher than $50 \mathrm{wt} \%$ ethylene glycol had high viscosity and were difficult to mix. For this reason, the maximum ethylene glycol level was set at $50 \mathrm{wt} \%$. Tween 80 and sodium chloride were also included at moderate levels of 0.1 and $1 \mathrm{wt} \%$, respectively, because their presence was found to reduce enzyme adsorption to plastic vials used in sample processing and assays (data not shown).

\section{Microbial Activity During Successive Enrichments of Switchgrass and Corn Stover}

For all enrichment incubations with a particular feedstock, replicate treatments had similar respiration profiles (Fig. 1). 

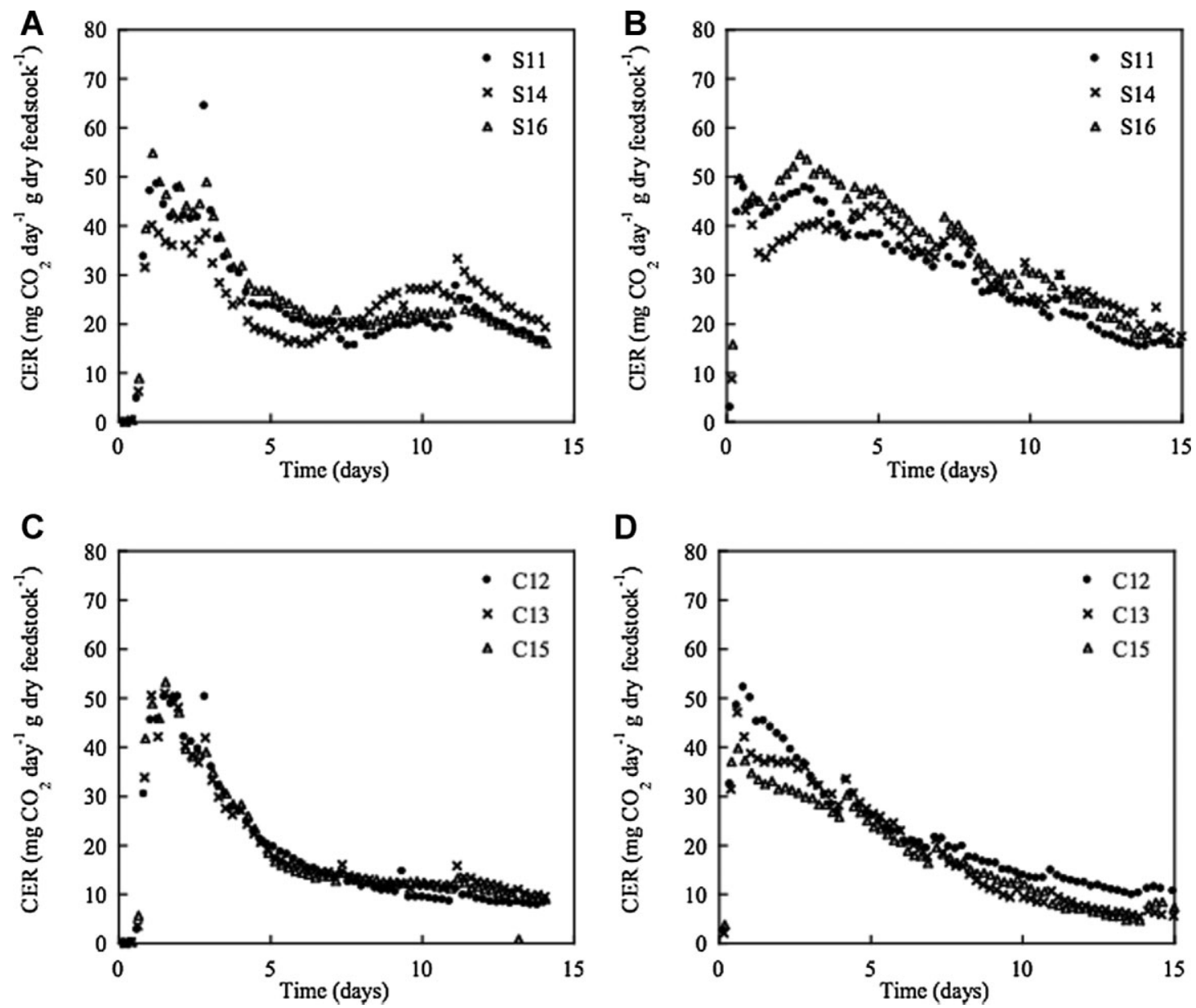

Figure 1. Carbon dioxide evolution rate profiles for the first (T1) and last (T4) 2 weeks of the enrichment study for individual reactors: (A) switchgrass, T1, (B) switchgrass, T4, (C) corn stover, T1, and (D) corn stover, T4.

Respiration profiles for the first pass (T1) are shown in Figure $1 \mathrm{~A}$ and $\mathrm{C}$ for switchgrass and corn stover, respectively. During the first 2 -week incubation, respiration rate peaked around 1.5 days and dropped significantly for both feedstocks. On day 11, a second peak occurred for switchgrass, indicating adaptation of the community to decompose recalcitrant compounds under thermophilic conditions.

Successive respiration profiles showed a more sustained period of activity after the transfer and then a steady decline. This trend was consistent for all time points after T1. Respiration profiles for the last enrichment of the study (T4) are shown in Figure 1B and D for switchgrass and corn stover, respectively. Microbial activity on both feedstocks peaked in less than one day and steadily declined. Peak respiration rates varied between 40 and $50 \mathrm{mg} \mathrm{CO}_{2}$ day $^{-1} \mathrm{~g}$ $\mathrm{dw}^{-1}$ for both feedstocks; however, corn stover respiration rates declined more rapidly compared to switchgrass. This led to differences in cumulative respiration between feedstocks.
In general, total microbial activity, represented as cumulative carbon dioxide evolution (cCER), was greater on switchgrass than on corn stover (Table II). cCER increased with each transfer for switchgrass. For corn stover, cCER was greatest after the second 2-week incubation (T2) and remained relatively constant with successful enrichments. After each 2-week incubation period, adapted communities reduced solids an average of $30 \%$ for switchgrass and $22 \%$ for corn stover (Table II). Overall, the changes for switchgrass were more pronounced than for corn stover; solids reduction between the first and second time points increased by a factor of four for switchgrass while reduction remained relatively constant for corn stover.

\section{Enzyme Activity}

Enzymes were extracted from feedstocks with the selected buffer containing $1 \mathrm{wt} \%$ sodium chloride, $0.1 \mathrm{wt} \%$ Tween 80 
Table II. Cumulative carbon dioxide evolution rate (cCER) and solids reduction of bioreactors measured after each 2-week incubation (T1-T4).

\begin{tabular}{|c|c|c|c|c|}
\hline \multirow[b]{2}{*}{$\begin{array}{l}\text { Sampling } \\
\text { point }\end{array}$} & \multicolumn{2}{|c|}{ Switchgrass } & \multicolumn{2}{|c|}{ Corn stover } \\
\hline & $\begin{array}{c}\text { Average cCER } \\
\left(\mathrm{mg} \mathrm{CO}_{2} \text { g dry feedstock }^{-1}\right)\end{array}$ & $\begin{array}{l}\text { Average reduction } \\
\text { in total solids ( } \mathrm{wt} \%)\end{array}$ & $\begin{array}{c}\text { Average cCER } \\
\left(\mathrm{mg} \mathrm{CO}_{2} \mathrm{~g} \text { dry feedstock } \mathrm{IU} \mathrm{g} \mathrm{dw}^{-1}\right)\end{array}$ & $\begin{array}{l}\text { Average reduction } \\
\text { in total solids (wt } \%)\end{array}$ \\
\hline $\mathrm{T} 1$ & 349 & 8 & 264 & 19 \\
\hline $\mathrm{T} 2$ & 424 & 29 & 355 & 22 \\
\hline $\mathrm{T} 3$ & 433 & 28 & 304 & 22 \\
\hline $\mathrm{T} 4$ & 466 & 34 & 288 & 23 \\
\hline
\end{tabular}

and $50 \mathrm{wt} \%$ ethylene glycol. Enzyme activity increased for each successive transfer of switchgrass (Fig. 2). From T1 to T4, xylanase and endoglucanase activity increased by more than a factor of five. This corresponds to the increase in cCER and increase in solids reduction with each successive transfer (Table II).

Enzyme activities were lower for corn stover compared to switchgrass and showed less variation with time (Fig. 2), corresponding to the relatively constant CCER and solids reduction with enrichment. With the exception of xylanase activity in $\mathrm{C} 13$, the most activity for corn stover enrichments was seen at $\mathrm{T} 2$, the time point with the highest cCER.

\section{Microbial Community Structure and Dynamics}

Microbial community structure was determined for all samples after each 2-week incubation (T1-T4) using SSU rRNA gene amplicon pyrosequencing. All enrichment cultures indicated a wealth of phylogenetic diversity
A
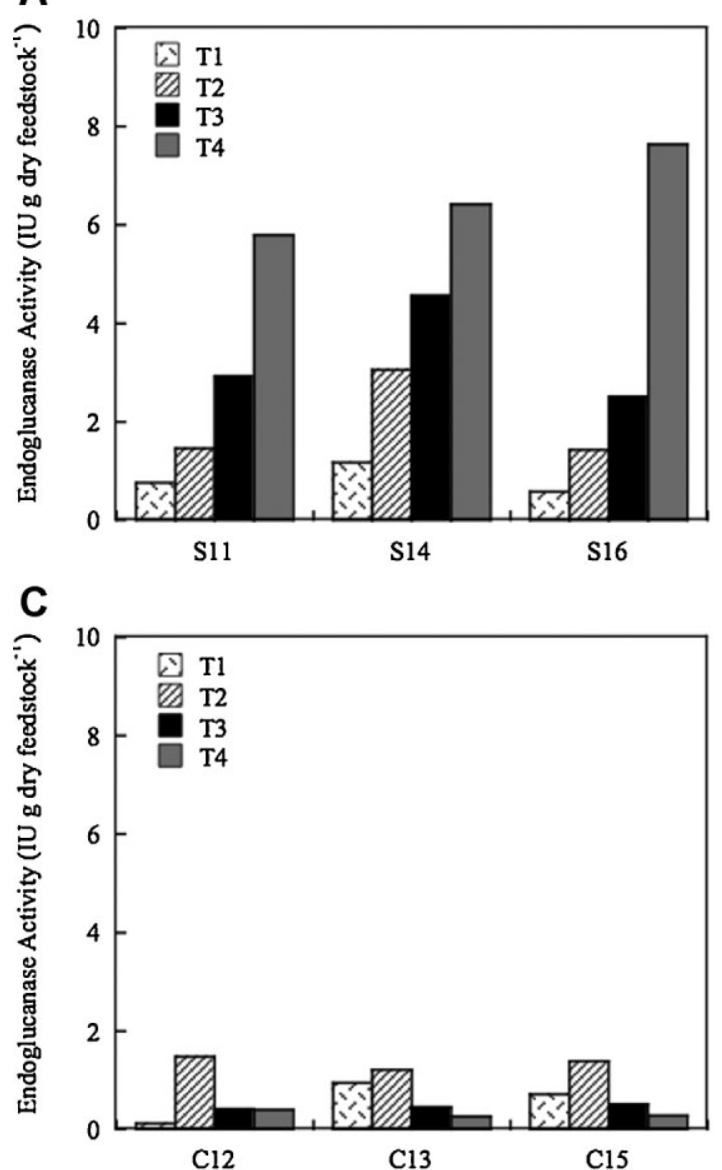

B

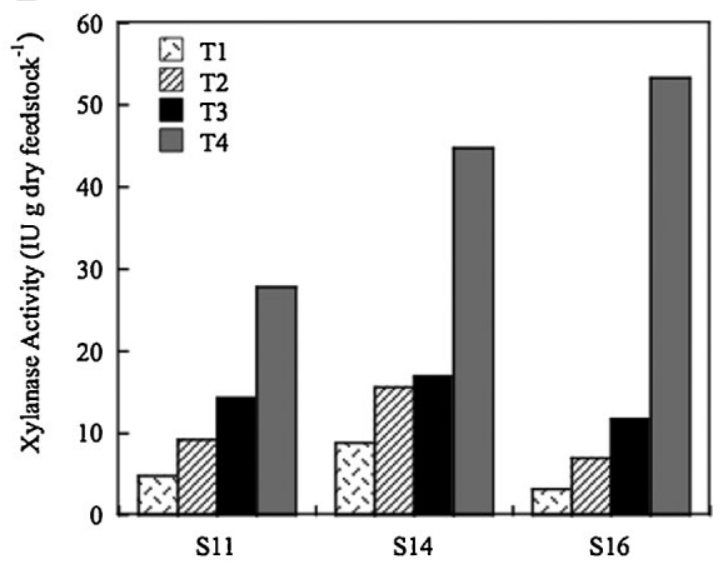

D

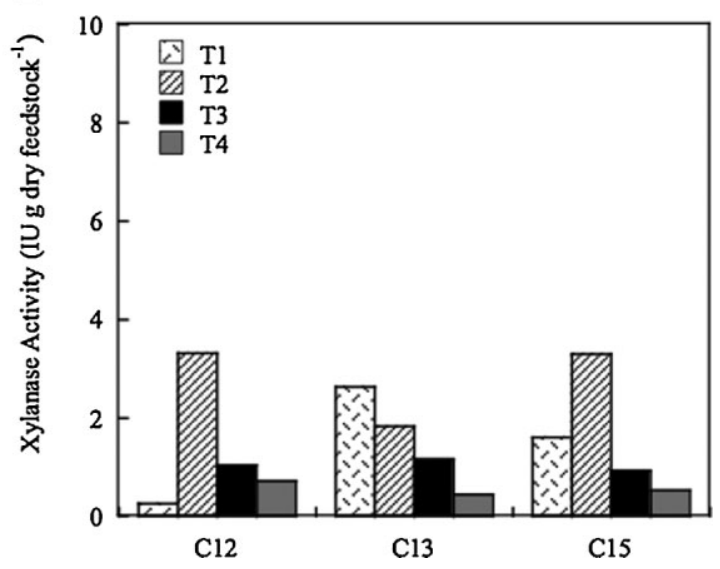

Figure 2. Endoglucanase and xylanase activities at end of each 2-week incubation period for individual reactors (R): (A) endoglucanase activity extracted from switchgrass, (B) xylanase activity extracted from switchgrass, (C) endoglucanase activity extracted from corn stover, and (D) xylanase activity extracted from corn stover. 
Table III. Temporal changes of microbial community on switchgrass (S) and corn stover (C) after each 2-week incubation (T1-T4): (a) Shannon Diversity Index and (b) richness (no. OTUs).

\begin{tabular}{|c|c|c|c|c|c|}
\hline Reactor \# & Feedstock & $\mathrm{T} 1$ & $\mathrm{~T} 2$ & T3 & $\mathrm{T} 4$ \\
\hline \multicolumn{6}{|c|}{ (a) Shannon Diversity Index } \\
\hline S11 & Switchgrass & 3.77 & 2.15 & 2.36 & 2.14 \\
\hline S14 & Switchgrass & 3.67 & 2.47 & 2.53 & 2.40 \\
\hline S16 & Switchgrass & 3.96 & 2.70 & 2.76 & 2.47 \\
\hline $\mathrm{C} 12$ & Corn stover & 4.19 & 3.13 & 3.02 & 3.11 \\
\hline $\mathrm{C} 13$ & Corn stover & 3.92 & 3.80 & 3.06 & 2.93 \\
\hline C15 & Corn stover & 4.12 & 3.76 & 3.09 & 3.09 \\
\hline \multicolumn{6}{|c|}{ (b) Richness (no. OTUs) } \\
\hline S11 & Switchgrass & 231 & 116 & 102 & 78 \\
\hline S14 & Switchgrass & 309 & 119 & 124 & 165 \\
\hline S16 & Switchgrass & 381 & 126 & 136 & 105 \\
\hline $\mathrm{C} 12$ & Corn stover & 397 & 185 & 161 & 163 \\
\hline C13 & Corn stover & 245 & 196 & 177 & 107 \\
\hline C15 & Corn stover & 387 & 224 & 159 & 141 \\
\hline
\end{tabular}

including bacteria and fungi, which decreased over time, independent of the substrates used (Table III).

Temporal succession in microbial diversity was also reflected in overall community composition as indicated by NMDS comparisons (Fig. 3). The most dramatic shift in community composition occurred after $\mathrm{T} 1$ for both the switchgrass and corn stover communities. After T2 the communities stabilized and the changes in composition were only minor. However, in the corn stover enrichments, the T2 samples indicate an intermediate stage between the $\mathrm{T} 1$ and the $\mathrm{T} 3$ and $\mathrm{T} 4$ samples by forming its own discrete cluster (Fig. 3).

As summarized in Tables IV and V, some microorganisms were heavily enriched on the provided substrates whereas others completely disappeared. For example, a member of the genus Microbispora increased in relative abundance from initial $1 \%$ to over $30 \%$ at the later time points. At the same time a member of the genus Dactylosporangium disappeared even though being dominant $(>10 \%)$ in the T1 samples.

To determine if the two substrates enriched for different communities, the T4 samples were compared using SIMPER (SIMilarity PERcentage) (Table VI). This method assesses which taxa are primarily responsible for differences between switchgrass and corn stover enriched communities. The four organisms related to the genera Cohnella (Cluster 3), Chelatococcus (Cluster 4), Niabella (Cluster 6), and the family Sinobacteraceae (Cluster 5) contributed most to the observed differences between the two substrates. Whereas members of Cluster 3, 4, and 6 appear to preferentially grow on switchgrass, and Cluster 5 appears to be unique to corn stover.

\section{Discussion}

Switchgrass and corn stover were incubated in a high-solids environment at $55^{\circ} \mathrm{C}$ with continuous aeration to simulate a composting process. Prior to initiating enrichment
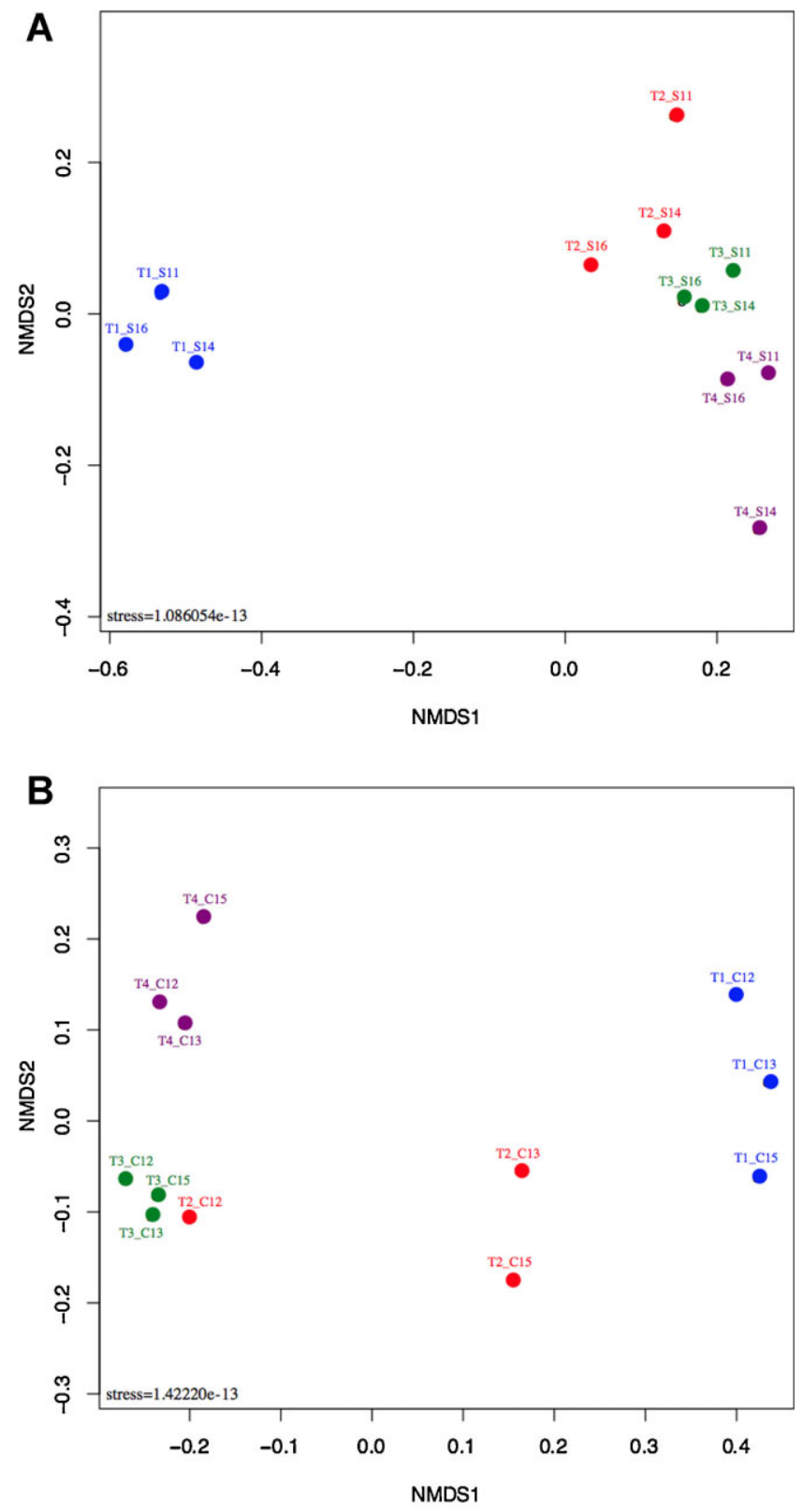

Figure 3. Shift of microbial community after each 2-week incubation (T1-T4). NMDS of (A) switchgrass (S), and (B) corn stover (C) communities. [Color figure can be seen in the online version of this article, available at http://wileyonlinelibrary.com/bit]

incubations, experiments were completed to identify extraction compounds required for recovery of enzymes from each feedstock. Three compounds that yielded positive results for other high solids biological systems were examined. Tween 80 , a surfactant that disrupts non-specific binding of enzymes to substrates, was selected based on its positive effect on the desorption and recycling of cellulases during saccharification of crystalline cellulose and pretreated pine (Otter et al., 1989; Tu et al., 2007). Sodium chloride was investigated to increase the ionic strength of the buffer and disrupt interactions between protonated groups 
Table IV. Changes in relative abundance of selected OTUs in the switchgrass (S) microbial community over time.

\begin{tabular}{lrrrrl}
\hline OTU & T1 & T2 & T3 & T4 & Taxonomy; greengenes ID (http://greengenes.lbl.gov) \\
\hline S11 & & & & & \\
Cluster1 & 0.9 & 32.8 & 36.6 & 35.1 & Microbispora (Actinobacteria); 12149 \\
Cluster3 & 2.1 & 37.1 & 17.7 & 15.5 & Cohnella (Firmicutes); 27158 \\
Cluster4 & 2.8 & 2.6 & 8.3 & 19.2 & Chelatococcus (Proteobacteria); 232942 \\
Cluster5 & 7.9 & 0.0 & 0.0 & 0.0 & Sinobacteraceae (Gammaproteobacteria); 210648 \\
Cluster11 & 10.5 & 0.1 & 0.1 & 0.2 & Dactylosporangium (Actinobacteria); 336366 \\
Cluster13 & 10.2 & 0.2 & 0.0 & 0.0 & Sinobacteraceae (Gammaproteobacteria); 219056 \\
Cluster51 & 9.8 & 1.8 & 0.2 & 0.0 & Bacillales (Firmicutes); 14393 \\
S14 & & & & \\
Cluster1 & 0.7 & 32.9 & 29.9 & 17.5 & Microbispora (Actinobacteria); 12149 \\
Cluster3 & 0.9 & 25.5 & 16.2 & 20.7 & Cohnella (Firmicutes); 27158 \\
Cluster4 & 3.4 & 2.4 & 9.4 & 10.3 & Chelatococcus (Proteobacteria); 232942 \\
Cluster11 & 20.6 & 0.2 & 0.0 & 0.0 & Dactylosporangium (Actinobacteria); 336366 \\
Cluster29 & 7.6 & 0.9 & 0.1 & 1.1 & \\
S16 & & & & Microbispora (Actinobacteria); 12149 \\
Cluster1 & 0.5 & 30.1 & 25.4 & 34.4 & Cohnella (Firmicutes); 27158 \\
Cluster3 & 1.2 & 24.6 & 16.2 & 11.1 & Chelatococcus (Proteobacteria); 232942 \\
Cluster4 & 2.2 & 3.1 & 15.2 & Dactylosporangium (Actinobacteria); 336366 \\
Cluster11 & 10.6 & 0.3 & 0.0 & Sinobacteraceae (Gammaproteobacteria); 219056 \\
Cluster13 & 8.0 & 0.6 & 0.2 & 0.0 & Bacillales (Firmicutes); 14393 \\
Cluster51 & 6.2 & 1.0 & 0.2 & & \\
\hline
\end{tabular}

on proteins and feedstocks. It assisted in the recovery of xylanase from sugarcane bagasse (Maciel et al., 2009). The third component was ethylene glycol, which was selected to disrupt hydrophobic interactions. It also had a positive effect on the recovery of enzymes during recycling (Otter et al., 1989; Tu et al., 2007).

Ethylene glycol had the most significant effect on the extraction of enzymes from both switchgrass and corn stover. For xylanase, extracted activity doubled when ethylene glycol increased from 0 to $50 \mathrm{wt} \%$ in the buffer. This implies strong hydrophobic interactions between the enzymes and substrate. The carbohydrate-binding modules (CBM) of well-studied glycoside hydrolases have been shown to include polar residues that would facilitate hydrophobic interactions between proteins and polysaccharides (Beckham et al., 2010). The fact that ethylene glycol had such a significant impact on extracted enzyme activity suggests an enrichment of enzymes with CBMs. In systems that use insoluble substrates for enrichment of enzymes active on cell walls, enzyme-polysaccharide interactions would need to be disrupted for efficient recovery of enzymes. Ethylene glycol appears to be a viable compound to accomplish disruption.

Long-term enrichments were carried out by incubating feedstocks and transferring the established community to fresh feedstock every 2 weeks. For switchgrass the increase in microbial activity, enzyme activities and solids reduction indicate continuing adaptation as a function of enrichment. In contrast to switchgrass, there was a decline in microbial activity and enzyme activities after T2 enrichments with corn stover. The decline in activity suggests that compounds inhibitory to microbial and enzymatic activity accumulated during enrichments. A recent report indicated that extracts from corn stover (extracted using $\mathrm{pH} 7$ buffer) included

Table V. Changes in relative abundance of selected OTUs in the corn stover (C) microbial community over time.

\begin{tabular}{|c|c|c|c|c|c|}
\hline OTU & $\mathrm{T} 1$ & $\mathrm{~T} 2$ & T3 & $\mathrm{T} 4$ & Taxonomy; greengenes ID (http://greengenes.lbl.gov) \\
\hline \multicolumn{6}{|l|}{$\mathrm{C} 12$} \\
\hline Cluster1 & 0.4 & 28.7 & 29.5 & 23.5 & Microbispora (Actinobacteria); 12149 \\
\hline Cluster3 & 2.8 & 10.7 & 6.4 & 1.2 & Cohnella (Firmicutes); 27158 \\
\hline Cluster8 & 0.1 & 5.8 & 6.2 & 0.5 & Sphingomonadales (Proteobacteria); 180031 \\
\hline Cluster9 & 6.0 & 4.6 & 6.6 & 10.8 & Acidobacteria; 113347 \\
\hline \multicolumn{6}{|l|}{$\mathrm{C} 13$} \\
\hline Cluster1 & 0.5 & 8.0 & 36.0 & 30.2 & Microbispora (Actinobacteria); 12149 \\
\hline Cluster5 & 7.2 & 6.9 & 2.8 & 20.6 & Sinobacteraceae (Gammaproteobacteria); 210648 \\
\hline Cluster11 & 9.7 & 7.0 & 1.3 & 1.1 & Dactylosporangium (Actinobacteria); 336366 \\
\hline \multicolumn{6}{|r|}{ 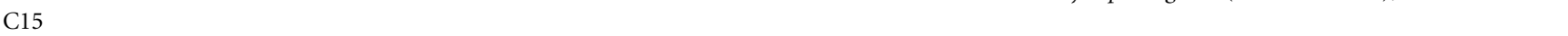 } \\
\hline Cluster1 & 1.2 & 4.7 & 34.3 & 19.5 & Microbispora (Actinobacteria); 12149 \\
\hline Cluster5 & 3.9 & 5.1 & 2.8 & 17.2 & Sinobacteraceae (Gammaproteobacteria); 210648 \\
\hline Cluster11 & 12.2 & 8.8 & 0.9 & 0.4 & Dactylosporangium (Actinobacteria); 336366 \\
\hline
\end{tabular}


Table VI. SIMPER analysis between T4 microbial communities of higher-contributing ( $>75 \%$ cumulative contribution) OTUs.

\begin{tabular}{|c|c|c|c|c|}
\hline OTU & $\begin{array}{l}\text { Average abundance } \\
\text { switchgrass }\end{array}$ & $\begin{array}{l}\text { Average abundance } \\
\text { corn stover }\end{array}$ & $\begin{array}{c}\text { Contribution } \\
(\%)\end{array}$ & $\begin{array}{l}\text { Taxonomy; greengenes ID } \\
\text { (http://greengenes.lbl.gov) }\end{array}$ \\
\hline Cluster5 & 0.00 & 17.17 & 14.78 & Sinobacteraceae; 210648 \\
\hline Cluster3 & 15.79 & 2.00 & 11.87 & Cohnella; 27158 \\
\hline Cluster4 & 14.88 & 3.61 & 9.70 & Chelatococcus; 232942 \\
\hline Cluster6 & 10.12 & 0.40 & 8.37 & Niabella; 270397 \\
\hline Cluster1 & 29.02 & 24.38 & 7.91 & Microbispora; 12149 \\
\hline Cluster9 & 0.00 & 8.16 & 7.03 & Acidobacteria; 113347 \\
\hline Cluster8 & 5.19 & 0.51 & 4.02 & Sphingomonadales; 180031 \\
\hline Cluster30 & 0.28 & 3.76 & 2.99 & Brevibacillus; 358085 \\
\hline Cluster14 & 5.64 & 3.46 & 2.96 & Schlegelella; 99971 \\
\hline Cluster28 & 0.00 & 2.42 & 2.08 & Sinobacteraceae; 239420 \\
\hline Cluster46 & 0.00 & 1.78 & 1.53 & Inquilinus; 150158 \\
\hline Cluster13 & 0.00 & 1.73 & 1.48 & Sinobacteraceae; 219056 \\
\hline
\end{tabular}

lignin-derived compounds that could be particularly inhibitory to microorganisms (Du et al., 2010). Possible inhibitory compounds include phenolic compounds, which are a byproduct of lignin degradation (Almeida et al., 2007; Palmqvist and Hahn-Hagerdal, 2000). Lignin has been shown to decrease growth and enzyme activity in Trichoderma reesei (Vohra et al., 1980) and lignin-derived compounds have been shown to inhibit cellulases and xylanases produced by thermophilic bacteria (Joh et al., 2011; Ximenes et al., 2010). To prevent inhibition in future adaptation studies, enriched samples could be leached prior to inoculating subsequent batches of feedstock. This approach was successful in prolonging growth and enzyme production by Acidothermus cellulolyticus during high-solids fermentation of switchgrass (Rezaei et al., 2011).

Pyrosequencing data showed simplification/specialization of the microbial community for both switchgrass and corn stover indicating selection of a few dominant community members adapted for the synergistic decomposition of these feedstocks in a high-solids, thermophilic environment. The dominant members of the adapted community (T4) on switchgrass were likely members of the genera Microbispora, Cohnella, and Chelatococcus, whereas on corn stover bacteria related to the genus Microbispora, the family Sinobacteraceae and the phylum Acidobacteria were predominant. Several members of the genus Microbispora have been isolated from high-solids environments and have demonstrated high levels of activity on xylan and other plant cell wall feedstocks (Hong et al., 2009). One approach for isolation of Microbispora from soil is treatment of samples under dry heat (Hayakawa et al., 1991). In addition, some species of Microbispora produce potent antibiotics (Foulston and Bibb, 2010). The combination of antibiotic production and tolerance to dry conditions may have led to the dominance of Microbispora in both switchgrass and corn stover enrichments. Their presence may have also played a role in the microbial adaptation process.

Members of the genus Cohnella have been previously isolated from compost samples and successfully grown on cellulose, carboxymethyl cellulose and sawdust under thermophilic conditions (Rastogi et al., 2010). A recent study isolated a strain of Cohnella from landfill soil (Kim et al., 2010). This strain possessed xylanase activity under moderately thermophilic conditions. The ability to decompose xylan likely favored the enrichment of Cohnella on switchgrass in our study. Chelatococcus have been isolated from hot springs and identified in mature compost piles (Panday and Das, 2010; Székely et al., 2009) though have not been presented as a dominant community member in prior studies. To our knowledge, this is the first report of their significance in a microbial community involved in cell wall polysaccharide decomposition under thermophilic conditions. Members of the family Sinobacteraceae have been identified in aged hydrocarbon polluted soil indicating their tolerance to nutrient deprived environments (Militon et al., 2010). Like Chelatococcus this is the first report of Sinobacteraceae enrichment in a thermophilic environment. It is not surprising to find Acidobacteria on several of the enriched corn stover samples as they are commonly identified in microbial communities in thermophilic environments such as compost and are known to tolerate nutrient deprived and dry environments (Allgaier et al., 2010; Székely et al., 2009; Ulrich et al., 2008; Ward et al., 2009).

The corn stover and switchgrass in this study were inoculated with the same source of green waste compost and incubated under identical conditions (temperature and aeration) simultaneously. The microbial community diverged by the first sampling point (T1) and resulted in different dominant members at all points of the enrichment study. Divergence of the community, even though both samples started with the same inocula, indicates the plant biomass source has an important impact on the types of organisms enriched. Enzyme activities, in particular xylanase, were much greater in switchgrass enrichments compared to corn stover. Such differences in the enriched community and enzyme activities demonstrate the need for specialized metabolic pathways and activities that depend on the unique plant cell wall polysaccharide composition of biofuel feedstocks. 
We thank Dean C. Dibble, Josh Claypool, Hiroyuki Kashima, and Lauren Jabusch for assistance with experiments. Tijana Glavina del Rio, Susannah Tringe, and Crystal Wright of the DOE Joint Genome Institute are acknowledged for their assistance in obtaining pyrotag sequencing data. This work was performed as part of the DOE Joint BioEnergy Institute (http://www.jbei.org) supported by the US Department of Energy, Office of Science, Office of Biological and Environmental Research, through contract DE-AC02-05CH11231 between Lawrence Berkeley National Laboratory and the US Department of Energy. Pyrotag sequencing was conducted by the Joint Genome Institute which is supported by the Office of Science of the US Department of Energy under Contract No. DE-AC0205CH11231.

\section{References}

Allgaier M, Reddy AP, Park JI, Ivanova N, D'haeseleer P, Lowry S, Sapra R, Hazen TC, Simmons BA, VanderGheynst JS, Hugenholtz P. 2010. Targeted discovery of glycoside hydrolases from a switchgrass-adapted compost community. PLoS One 5(1):e8812.

Almeida JRM, Modig T, Petersson A, Hahn-Hagerdal B, Liden G, GorwaGrauslund MF. 2007. Increased tolerance and conversion of inhibitors in lignocellulosic hydrolysates by Saccharomyces cerevisiae. J Chem Technol Biotechnol 82(4):340-349.

Bailey MJ, Biely P, Poutanen K. 1992. Interlaboratory testing of methods for assay of xylanase activity. J Biotechnol 23(3):257-270.

Beckham GT, Matthews JF, Bomble YJ, Bu L, Adney WS, Himmel ME, Nimlos MR, Crowley MF. 2010. Identification of amino acids responsible for processivity in a family 1 carbohydrate-binding module from a fungal cellulase. J Phys Chem B 114(3):1447-1453.

Bohlmann GM. 2006. Process economic considerations for production of ethanol from biomass feedstocks. Ind Biotechnol 2(1):14-20.

Chandra R, Bura R, Mabee W, Berlin A, Pan X, Saddler J. 2007. Substrate pretreatment: the key to effective enzymatic hydrolysis of lignocellulosics? Adv Biochem Engin Biotechnol 108:67-93.

Du B, Sharma LN, Becker C, Chen SF, Mowery RA, van Walsum GP, Chambliss CK. 2010. Effect of varying feedstock-pretreatment chemistry combinations on the formation and accumulation of potentially inhibitory degradation products in biomass hydrolysates. Biotechnol Bioeng 107(3):430-440.

Engelbrektson A, Kunin V, Wrighton KC, Zvenigorodsky N, Chen F, Ochman H, Hugenholtz P. 2010. Experimental factors affecting PCR-based estimates of microbial species richness and evenness. ISME J 4:642-647.

Foulston LC, Bibb MJ. 2010. Microbisporicin gene cluster reveals unusual features of lantibiotic biosynthesis in actinomycetes. Proc Natl Acad Sci 107(30):13461-13466.

Gerbens-Leenes W, Hoekstra AY, van der Meer TH. 2009. The water footprint of bioenergy. Proc Natl Acad Sci USA 106(25):1021910223.

Hayakawa M, Sadakata T, Kajiura T, Nonomura H. 1991. New methods for the highly selective isolation of Micromonospora and Microbispora from soil. J Ferment Bioeng 72(5):320-326.

Hong M-R, Kim Y-S, Park C-S, Lee J-K, Kim Y-S, Oh D-K. 2009. Characterization of a recombinant [beta]-glucosidase from the thermophilic bacterium Caldicellulosiruptor saccharolyticus. J Biosci Bioeng 108(1):36-40.

Joh LD, Rezaei F, Barabote RD, Parales JV, Parales RE, Berry AM, VanderGheynst JS. 2011. Effects of phenolic monomers on growth of Acidothermus cellulolyticus. Biotechnol Prog 27(1):23-31.

Kim DY, Han MK, Oh H-W, Bae KS, Jeong T-S, Kim SU, Shin D-H, Kim IH, Rhee YH, Son K-H, Park H-Y. 2010. Novel intracellular GH10 xylanase from Cohnella laeviribosi HY-21: biocatalytic properties and alterations of substrate specificities by site-directed mutagenesis of Trp residues. Bioresour Technol 101(22):8814-8821.

Kulkarni N, Shendye A, Rao M. 1999. Molecular and biotechnological aspects of xylanases. FEMS Microbiol Rev 23(4):411-456.

Kunin V, Engelbrektson A, Ochman H, Hugenholtz P. 2010. Wrinkles in the rare biosphere: pyrosequencing errors can lead to artificial inflation of diversity estimates. Environ Microbiol 12(1):118-123.

Maciel G, de Souza Vandenberghe L, Fendrich R, Della Bianca B, Haminiuk C, Soccol C. 2009. Study of some parameters which affect xylanase production: strain selection, enzyme extraction optimization, and influence of drying conditions. Biotechnol Bioprocess Eng 14(6):748-755.

Marshall MN, Reddy AP, VanderGheynst JS. 2004. Microbial ecology of compost. In: Lens P, Hamelers B, Hoitink H, Bidlingmaier W, editors. Resource recovery and reuse in organic solid waste management. London: IWA Publishing, pp. 193-224.

Merino S, Cherry J. 2007. Progress and challenges in enzyme development for biomass utilization. In: Olsson L, editor. Biofuels. Berlin/Heidelberg: Springer, pp. 95-120.

Militon C, Boucher D, Vachelard C, Perchet G, Barra V, Troquet J, Peyretaillade E, Peyret P. 2010. Bacterial community changes during bioremediation of aliphatic hydrocarbon-contaminated soil. FEMS Microbiol Ecol 74(3):669-681.

Otter DE, Munro PA, Scott GK, Geddes R. 1989. Desorption of Trichoderma reesei cellulase from cellulose by a range of desorbents. Biotechnol Bioeng 34(3):291-298.

Palmqvist E, Hahn-Hagerdal B. 2000. Fermentation of lignocellulosic hydrolysates. II: inhibitors and mechanisms of inhibition. Bioresour Technol 74(1):25-33.

Panday D, Das SK. 2010. Chelatococcus sambhunathii sp. nov., a moderately thermophilic alphaproteobacterium isolated from hot spring sediment. Int J Syst Evol Microbiol 60(4):861-865.

Rastogi G, Bhalla A, Adhikari A, Bischoff KM, Hughes SR, Christopher LP, Sani RK. 2010. Characterization of thermostable cellulases produced by Bacillus and Geobacillus strains. Bioresour Technol 101(22):8798-8806.

Reddy AP, Jenkins BM, VanderGheynst JS. 2009. The critical moisture range for rapid microbial decomposition of rice straw during storage. Trans Asabe 52(2):673-677.

Rezaei F, Joh LD, Berry AM, VanderGheynst JS. 2011. Enzyme production and extraction from solid fermentation of Acidothermus cellulolyticus on switchgrass. Biofuels 2(1):21-32.

Rubin EM. 2008. Genomics of cellulosic biofuels. Nature 454(7206):841845.

Schmer MR, Vogel KP, Mitchell RB, Perrin RK. 2008. Net energy of cellulosic ethanol from switchgrass. Proc Natl Acad Sci USA 105(2):464-469.

Spatari S, Zhang Y, MacLean HL. 2005. Life cycle assessment of switchgrassand corn stover-derived ethanol-fueled automobiles. Environ Sci Technol 39(24):9750-9758.

Székely A, Sipos R, Berta B, Vajna B, Hajdú C, Márialigeti K. 2009. DGGE and T-RFLP analysis of bacterial succession during mushroom compost production and sequence-aided T-RFLP profile of mature compost. Microb Ecol 57(3):522-533.

Tu M, Chandra RP, Saddler JN. 2007. Recycling cellulases during the hydrolysis of steam exploded and ethanol pretreated lodgepole pine. Biotechnol Prog 23(5):1130-1137.

Ulrich A, Klimke G, Wirth S. 2008. Diversity and activity of cellulosedecomposing bacteria, isolated from a sandy and a loamy soil after long-term manure application. Microb Ecol 55(3):512-522.

VanderGheynst JS, Walker LP, Parlange JY. 1997. Energy transport in a high-solids aerobic degradation process: mathematical modeling and analysis. Biotechnol Prog 13(3):238-248.

Vohra RM, Shirkot CK, Dhawan S, Gupta KG. 1980. Effect of lignin and some of its components on the production and activity of cellulase(s) by Trichoderma reesei. Biotechnol Bioeng 22(7):1497-1500. 
Ward NL, Challacombe JF, Janssen PH, Henrissat B, Coutinho PM, Wu M, Xie G, Haft DH, Sait M, Badger J, Barabote RD, Bradley B, Brettin TS, Brinkac LM, Bruce D, Creasy T, Daugherty SC, Davidsen TM, DeBoy RT, Detter JC, Dodson RJ, Durkin AS, Ganapathy A Gwinn-Giglio M, Han CS, Khouri H, Kiss H, Kothari SP, Madupu R, Nelson KE, Nelson WC, Paulsen I, Penn K, Ren Q, Rosovitz MJ, Selengut JD, Shrivastava S, Sullivan SA, Tapia R, Thompson LS, Watkins KL, Yang Q, Yu C, Zafar N, Zhou L, Kuske CR. 2009. Three genomes from the phylum Acidobacteria provide insight into the lifestyles of these microorganisms in soils. Appl Environ Microbiol 75(7):2046-2056.
Xiao ZZ, Storms R, Tsang A. 2005. Microplate-based carboxymethylcellulose assay for endoglucanase activity. Anal Biochem 342(1):176-178.

Ximenes E, Kim Y, Mosier N, Dien B, Ladisch M. 2010. Inhibition of cellulases by phenols. Enzyme Microb Technol 46(3-4):170-176.

Yang B, Wyman CE. 2008. Pretreatment: the key to unlocking low-cost cellulosic ethanol. Biofuels Bioprod Biorefin 2(1):26-40.

Zhang J, Chu D, Huang J, Yu Z, Dai G, Bao J. 2010. Simultaneous saccharification and ethanol fermentation at high corn stover solids loading in a helical stirring bioreactor. Biotechnol Bioeng 105(4):718728. 